\title{
THE PEREGRINE FALCON AND THE SORA
}

ROBERT W. NERO, 546 Coventry Road, Winnipeg, MB R3R 1 B6

Before dawn, the Peregrine Falcon flies steadily north over the top of the city and then out across fields. Ten minutes later it reaches the big marsh, and in the half-light skims over the reeds and water on set wings. Its flight is swift and surprisingly low. The sudden appearance of the falcon, just visible against a pearl-gray sky, startles a duck into flight, but the falcon courses onward. At a bay where marsh grasses give way to a pastured meadow the falcon circles once, silently, then with a burst of speed it cuts across the pasture. In the short, damp grass two Soras feed hurriedly, picking numb grasshoppers gleaming metallically in the dawn light. First one Sora, then the other rises in flight, fluttering awkwardly, feet dangling, to return to the safety of the marsh. But the falcon is upon them before they are aware of its presence; there is no perceptible pause as with one foot it snatches a Sora, lowers its head to crush the prey's head with its scimitar beak, and heads back towards the distant city, the Sora held tightly against its body.

When Gordon G. Graham found a dead Sora lying on the sidewalk on Broadway Avenue in downtown Winnipeg on March 8, 2000, his first thought was: "What is a Sora doing here at this time of the year?" Because the plumage appeared clean, Graham assumed that the carcass was fairly fresh. Upon closer examination at the office, however, it was determined that it was actually the old remains of a Sora, minus the head and one wing. This bird had probably been predated by a Peregrine Falcon the previous fall, partly eaten and left on top of a nearby building, then subsequently blown off by the strong wind on the day Graham found it. The location is not far from the Radisson Winnipeg Hotel (formerly Delta Winnipeg Hotel), a known nesting site of Peregrines. The female Peregrine that nested there the past 2 years has, in fact, overwintered locally.

The Sora Rail, or Sora as it is now officially known, is a long-legged, shorttailed bird, a little smaller than a Robin, residing in marshland habitat. Seldom seen in flight on the breeding grounds, these secretive birds are best known by their distinctive calls. Yet, they are capable fliers, migrating annually from northern wetlands to and from southern U.S. wintering grounds. C.W. Nash wrote: "Late in the autumn, just before migrating, this bird develops startling powers of flight...."12 Despite its small size, the prolific Sora is listed in several states and provinces as a game species.

Surprisingly, of all the prey species taken by Peregrines residing in downtown Winnipeg and Brandon, the little Sora is one of the most frequently taken, ranking second after Rock Doves (pigeons). The other top species are Black-billed Cuckoos, Northern Flickers and Pied-billed Grebes. "Sora, Northern Flicker, and Black-billed Cuckoo are relatively uncommon in Winnipeg as shown by the prey availability study, but they are selected for prey during the early to mid-season, suggesting that there is a local irruption of these two [sic.] species, or there is some energetic 
benefit to peregrines when they hunt these birds." 3

"The high number of Soras and Piedbilled Grebes found [at the former Delta Hotel, a Peregrine nest-site in downtown Winnipeg] suggests that the male was hunting marsh sites, perhaps even going as far as Oak Hammock [Marsh]. Shorebirds, including a Ruddy Turnstone in fall plumage, presumably taken last year, further support this idea."10

One early morning in the 1950s, while studying Red-winged Blackbirds at Madison, Wisconsin, I was surprised to find three Soras foraging in a grassy meadow dozens of yards from an adjacent marsh, picking their way through the short grass like little hens. I saw one or more Soras in a similar situation on two or three other occasions. More than a century ago at Portage la Prairie, Nash commented on the ability of the Sora to walk about: "just about the time of departure [in fall] it may be found in most unlikely places, and it is just possible that when so found it may have been travelling southwards on foot." 12 Street remarks how he caught an adult and a juvenile Sora at his banding station at Nipawin, Saskatchewan, more than a mile from water, May 3, 1945 and August 26, 1957. On the other hand, one spring morning in a residential area of Regina, I watched in surprise as a high-flying Sora killed itself when it struck a hydro wire behind our home.

Soras residing in my marsh study area at Madison often entered traps I'd set for Redwings and baited with white bread, in some instances going into traps three feet above the water. ${ }^{9}$ Jean Bancroft wrote about a Sora which she saw one day "perched on a branch of an oak tree, approximately 18 feet above the ground" at Whytewold, Manitoba, and she noted that Bent's account mentions only one such case, a bird seen settling onto a branch of a mangrove tree in Bermuda in 1847. ${ }^{1}$ Closer to home, at Brooks, Alberta, Randall found an active Sora nest on June 10, 1945, in a willow bush and four and one-half feet above the water. Fourteen eggs laid in this nest hatched successfully. ${ }^{11}$

The usual arrival date for the Sora in southern Manitoba is early May, the earliest arrival dates reported being May 1, 1977, at Oak Hammock Marsh, and May 4, 1976, in the southwest. ${ }^{5,8}$ The earliest arrival dates for Saskatchewan are: April 17, 1976 - Regina; April 27, 1958 - Qu'Appelle; April 18, 1933 Prince Albert; May 2, 1933 - Nipawin.2, 4, 7 In northern Minnesota, the earliest arrival is April 20, and April 1 in southern Minnesota. ${ }^{6}$ Of course, since we identify the Sora mostly by its call, it could be present in spring some time earlier than we're aware. This is a hardy species; one Sora even overwintered in southern Minnesota, November 30, 1893 to January $24,1894 .{ }^{6}$ The Sora has been recorded in Manitoba as late as October 16, 1976, at Oak Hammock. ${ }^{5}$ Callin reported one in the Qu'Appelle Valley, Saskatchewan, October 25, 1904. ${ }^{4}$

Peregrine Falcons are adept at finding and capturing prey, mostly birds in flight, from shorebirds to ducks - it is their way of life. Along with other Peregrine watchers I have looked on in wonder as they successfully pursued prey, but some things have puzzled me. Birders have difficulty finding Black-billed Cuckoos in and around Winnipeg, for example, yet Peregrines residing here seem to routinely pick them off. As to Pied-billed Grebes, a species seldom seen in flight, how Peregrines nab these skillful divers is a mystery. And the Sora as a prey species?! Clearly, Peregrines have special knowledge and hunting strategies as yet unrevealed. As Jim 
Duncan noted when he reviewed this article: "The unknown aspects, the element of surprise, this is what makes observing nature so compelling."

1. Bancroft, F. [Jean]. 1977. Sora in a tree. Blue Jay 35: 101.

2. Belcher, M. 1980. Birds of Regina. Revised ed. Special Publication No. 12, SNHS, Regina.151pp.

3. Berger, R.P., and D. Chranowski. 1993. Peregrine Falcon recovery project: Manitoba perspective. Pp. 333341 In Proc. Third Prairie Cons. \& Endangered Species Workshop. Nat. Hist. Occas. Paper No. 19. Prov. Mus. Alberta. Edmonton.

4. Callin, E.M. 1980. Birds of the Qu'Appelle, 1857-1979. Special Publication No. 13. SNHS, Regina. 168 pp.

5. Gardner, K.A. 1981. Birds of Oak Hammock Marsh Wildlife Mgt. Area. Man. Wild. Bn. Winnipeg. 172pp.
6. Green, J. C., and R.B. Janssen. 1975. Minnesota birds, where, when and how many. U. Minn. Press, Minneapolis. 217pp.

7. Houston, C.S., and M.G. Street. 1959. The birds of the Saskatchewan River, Carlton to Cumberland. Special Publication No. 2, SNHS, Regina. 205pp.

8. Knapton, R.W. 1979. Birds of the Gainsborough-Lyleton region. Special Publication No. 10, SNHS, Regina. 72pp.

9. Nero, R.W. 1984. Redwings. Smithsonian Institute Press, Washington, D.C. 160pp.

10. Nero, R.W. 1989. Heaven's own bird: Peregrine Falcons nest in Winnipeg. Manitoba Naturalists Society Bull. 14 (8): 15-16.

11. Randall, T.E. 1962. Unusual nest site of Sora. Blue Jay 20: 116.

12. Thompson, E.E. 1891. The birds of Manitoba. Second Ed. Premium Ventures Ltd. 1975, Winnipeg. 643pp.

\title{
OF RAVENS, GULLS AND A PELICAN
}

\author{
VICTOR C. FRIESEN, P.O. Box 65, Rosthern, SK SOK 3R0
}

A few years ago, I and two companions were diverted from our fishing at Damour Lake (north of Blaine Lake) by the aerial display of six Common Ravens. The flying gymnastics lasted more than an hour. A steep hill abutted one shore, and the birds were continually wheeling about, riding in and out of the rising air currents caused by strong winds. Dives, tumbles, and wing-overs were part of their performance.

Taverner describes ravens' behaviour as "sometimes very playful in the air." 2
Indeed, at times these birds appeared to be taking turns in soaring up and then swooping down; occasionally, two birds might engage in a similar movement jointly. What was most interesting to watch were the embellishments often added: a raven's apparent out-of-control tumble, with wings flapping about, then an easy recovery - or a smoothly executed flipping over onto its back, with wings fully extended, followed by another flip to right itself. These moves were often combined with a downward plunge, all accomplished just above the 